\title{
Finaalirakenne suomenkielisissä teksteissä 1500-luvulta nykysuomeen
}

\section{Johdanto}

Sekä puhutussa että kirjoitetussa suomen kielessä tunnetaan useita lausemaisia verbien nominaalimuotoihin perustuvia syntaktisia rakenteita. Tässä artikkelissa tarkastellaan näistä yhtä, finaalirakennetta (esim. Lähdin matkalle tutustuakseni paikkaan). Tarkastelun keskiössä on rakenteen esiintyminen kirjoitetussa kielessä. A-infinitiivin translatiiviin perustuva tarkoitusta ilmaiseva synteettinen rakenne on tunnettu kirjoitetussa suomessa sen alkuajoista lähtien, ja se on olennainen osa myös nyky-yleiskielen ilmaisuvarantoa. Ilmaisutyyppi on kaikkiaan marginaalinen, ja alhainen esiintymisfrekvenssi sekä määrittelemiseen liittyvät ongelmat ovat vaikuttaneet sen tutkittavuuteen ja alueellisen levikin kartoittamiseen puhutun kielen aineistoista (Ikola-Palomäki-Koitto 1989, 314-315). Vaikuttaa siltä, että finaalirakenne ei ole vanhastaan kuulunut erityisesti minkään alueen puhekieleen, vaan mahdollisesta puhekielisestä motivaatiosta huolimatta kysymys on kirjakielelle tyypillisestä rakenteesta. Samoja piirteitä on muissakin nominaalimuotoihin perustuvissa syntaktisissa rakenteissa (ks. esim. Ikola 1974; Wiik 1981; Hakanen 1986). Finaalirakenteen jokseenkin tuntematon tausta luo kiinnostavan lähtöasetelman sen kehityksen ja käytön tutkimukselle kirjoitetussa kielessä.

Käsillä oleva tutkimus koostuu neljästä osatutkimuksesta, joissa finaalirakenteen esiintymistä analysoidaan eri näkökulmista. ${ }^{1}$ Tarkastelun kohteina ovat rakenteen kehitys ja toteutuminen eri aikoina, eri tekstilajeissa ja eritaustaisilla kirjoittajilla. Lähestymistapa on sekä diakroninen että synkroninen. Tietty epäsymmetria osatutkimusten välillä johtuu osin vanhan kirjasuomen ja varhaisnykysuomen kirjallisten aineistojen asettamista rajoituksista, kuten siitä, että käytettävissä oleva data vaihtelee määrältään ja laadultaan eri aikoina, mutta myös artikkelin luonteesta. Artikkelin keskeisenä tarkoituksena on avata

1 Artikkelissa esitellyistä osatutkimuksista ensimmäisestä vastaa Duha Elsayed, toisesta Harri Uusitalo, kolmannesta Heidi Salmi ja neljännestä Kirsi-Maria Nummila. 
näkökulmia tarkasteltavaa aihetta käsittelevään jatkotutkimukseen. Tässä artikkelissa esiteltyjen osatutkimusten yhteisenä tavoitteena on selvittää, missä ja missä määrin finaalirakennetta on eri aikoina käytetty ja kuka sitä on käyttänyt.

Jokaista osatutkimusta varten on koostettu sen lähtökohtiin perustuva ja kysymyksenasetteluun vastaava tutkimusaineisto. Aineistot esitellään osatutkimusten yhteydessä. Jotta tutkimustulokset ovat vaivattomasti suhteutettavissa toisiinsa ja eri aineistoista tehdyt laskelmat ja päätelmät vertailukelpoisia, ovat kaikki osa-aineistot 35 ooo saneen laajuisia. Tarvittaessa esiintymäfrekvenssit on selvitetty suhteuttamalla todellinen sanemäärä 35 ooo saneeseen.

Artikkeli jakautuu osatutkimusten yhteistä taustaa esittelevään osaan ja varsinaiseen analyysiosaan. Tutkimuksen tarkoitusta ja tavoitteita käsittelevän johdantoluvun jälkeen luvussa 2 esitellään tarkasteltavana olevaa rakennetta morfologisesta ja syntaktisesta näkökulmasta ja kartoitetaan aiempaa tutkimusta. Luvussa 3 paneudutaan tutkimuskohteeseen edellä esitellyistä näkökulmista. Luvussa 4 kootaan yhteen osatutkimuksissa tehtyjä huomioita ja esitellään jatkotutkimusnäkymiä.

\section{Finaalirakenne}

\subsection{Finaalirakenteen määrittely nykysuomen ja käsillä olevan tutkimuksen näkökulmasta}

Finaalirakenne koostuu A-infinitiivin translatiivista, johon kuuluu pakollisena osana possessiivisuffiksi (tutustuakseni). Kuten translatiivimuotoiset lausekkeet usein, rakenne ilmaisee tarkoitusta. Sen tyypillisin analyyttinen vastine on jotta-sivulause (jotta tutustuisin). Semanttisesti finaalirakenteen paralleeleja ovat esimerkiksi rakenteet, joissa verbi on MA-infinitiivin illatiivissa (Hän lähti kisaan kokeilemaan rajojaan), passiivin VApartisiipin translatiivissa (Hän on liian nuori lähetettäväksi ulkomaille) tai A-infinitiivin perusmuodossa (Meillä ei ole rahaa tuhlata). Verbikantaisen -minen-johdoksen translatiivimuoto täyttää usein samaa tehtävää (Tunnustelut hallituksen muodostamiseksi ovat alkaneet). (ISK $\$ 513-514$.)

Suhteessa hallitsevaan lauseeseen finaalirakenne toimii adverbiaalimääritteenä. Infinitiiviin liittyvä possessiivisuffiksi viittaa päälauseen tavallisesti elollistarkoitteiseen subjektiin. Prototyyppisessä tapauksessa päälauseessa ja finaalirakenteessa ilmaistujen tekojen välillä on kausaalinen suhde: edellinen edistää jälkimmäisen toteutumista, kuten esimerkissä Hän on ponnistellut lujasti estääkseen neuvottelujen kariutumisen. Päälause voi ilmaista myös infinitiivirakenteessa ilmaistun toiminnan välttämätöntä tai tarpeellista ehtoa (Mutta hän ei ole elänyt tarpeeksi kauan kertoakseen löydöstään). Toisinaan tilanteen aikasuhteet nousevat kausaalista suhdetta tärkeämmiksi. Silloin finaalirakenne ilmaisee pelkästään päälauseessa ilmaistuun toimintaan verrattuna myöhempää toimintaa, esim. 
Edmonton meni jatkoon hävitäkseen seuraavalla kierroksella Minnesotalle. ${ }^{2}$ Tarkoituksen merkitys puuttuu kokonaan myös sellaisista metatekstuaalisista, tekstiä kommentoivista, ilmauksista kuin mainitakseni, palatakseni, nähdäkseni ja siteeratakseni. Prototyyppinen finaalirakenne on hallitsevan lauseen kanssa samasubjektinen. (ISK \$513-514.)

Perinteisesti finaalirakenne on määritelty yhdeksi lauseenvastikkeen lajiksi. Siihen vertautuvat esimerkiksi referatiivinen, temporaalinen ja nesessiivinen lauseenvastike. Määritelmän mukaan lauseenvastike on rakenne, joka edustaa täydellistä upotettua lausetta. Jokaisella upotetun lauseen jäsenellä on rakenteessa edustuksensa, eikä mikään hallitsevan lauseen konstituentti ole sen konstituentti. Finaalirakenteessa upotetun lauseen predikaattia edustaa A-infinitiivin translatiivi ja hallitsevan lauseen kanssa samatarkoitteista subjektia siihen liittynyt possessiivisuffiksi. Transitiivisessa tapauksessa finaalinen lauseenvastike saa oman objektin eikä siis jaa sitäkään hallitsevan lauseen kanssa (Ikola 1974, 49-50 ja 87-88). Kalevi Wiik $(1981,24)$ kutsuu viimeksi mainittua ehtoa pintamuodon eheyden vaatimukseksi. Iso suomen kielioppi (\$876) ilmoittaa luopuneensa lauseenvastike-käsitteen käytöstä, koska se aiheuttaa enemmän sekaannusta kuin lisää selvyyttä. Päälauseen kanssa objektin jakava (Pyysin vettä juodakseni) ja oman objektinsa saava (Pyysin lasin juodakseni vettä) finaalirakenne ovat sekä muodon että merkityksen osalta sukulaiskonstruktioita, joiden jakaminen eri kategorioihin ilmentää enemmän tutkijoiden luokitteluintoa kuin kielen todellisuutta.

Tässä tutkimuksessa finaalirakennetta tarkastellaan sellaisena kuin se on toteutunut kirjakielessä neljän ja puolen vuosisadan aikana. Tiukat finaalisen lauseenvastikkeen muotokriteerit soveltuvat huonosti erityisesti vanhimman tekstimateriaalin käsittelyyn (esim. Agricolan Sine teet minulle Sian keudhexeni). Tästä syystä hallitsevan lauseen ja tarkasteltavan synteettisen rakenteen subjektin samaviitteisyyden ja eriobjektisuuden vaatimuksista on luovuttu. Tutkimusaineisto on koottu kahden kriteerin varassa: 1) finaalirakenne vastaa tarkoitusta (ja siten sen tilalle voitaisiin merkityksen ratkaisevasti muuttumatta asettaa jotta-lause) ja 2) finaalirakenne on hallitsevassa lauseessa adverbiaalin asemassa. Tarkastelun ulkopuolelle jäävät siis A-infinitiivin translatiivin sisältävistä rakenteista kvantum- (tietääkseni, ymmärtääkseni) ja fatumrakenteet (Tauti menee, jos on mennäkseen) sekä sellaiset leksikaalistuneet A-infinitiivin translatiivit, joissa rakenteeseen kuuluvan objektin voi katsoa sulautuneen infinitiiviin (sain syödäkseni).

\subsection{Aiempi finaalirakennetta koskeva tutkimus}

Finaalirakenteen esiintymisfrekvenssejä on aiemmin kartoitettu murreaineistosta, käännöskielestä ja vanhasta kirjasuomesta. Murreaineistoista rakennetta ovat tarkastelleet Osmo Ikola, Ulla Palomäki ja Anna-Kaisa Koitto (1989, 313-324). Heidän mukaansa

2 Nykysuomen kielenohjailu on suhtautunut torjuvasti myöhemmyyttä osoittaviin tapauksiin, jotka eivät ilmaise tarkoitusta. Esimerkiksi yllä esitetyssä esimerkkitapauksessa ei ole kysymys siitä, että joukkue eteni jatkoon, jotta se häviäisi seuraavan pelinsä. Kielenhuollon suosituksen on katsottava vaikuttaneen tyypin käyttöön nykykirjakielessä. 
finaalirakenne on murteissa varsin harvinainen: aineistossa rakennetta esiintyy yli kolmekymmentä kertaa vähemmän kuin nyky-yleiskielen vertailuaineistossa. ${ }^{3}$ Käsillä olevan tutkimuksen aineistoihin suhteutettuna murreaineistossa esiintyy noin 0,4 ja yleiskielessä noin 14 finaalirakennetta 35000 sanetta kohden (ks. Ikola-Palomäki-Koitto 1989, VII, 314). Murreaineistossa upotetun lauseen ja hallitsevan lauseen tekijät ovat lähes aina samat, ja erisubjektisuutta esiintyykin vain yhdessä aineiston tapauksessa (ks. myös Ikola 1974, 49-50).

Sari Eskola (2002) on tutkinut väitöskirjassaan nykysuomen syntetisoivia rakenteita vertailemalla suomennettuja ja suoraan suomeksi kirjoitettuja kaunokirjallisia tekstejä. Tarkasteltavien suomennosten lähtötekstit ovat englannin- ja venäjänkielisiä. Tutkimus osoittaa, että finaalirakenne esiintyy käännöksissä yli kaksi kertaa useammin kuin supisuomalaisissa teksteissä. Eskola esittää, että syy ilmaisutyypin ylikorostumiseen käännössuomessa saattaa olla lähtökielisissä rakenteissa; valtaosa tapauksista vastaa englannin finaalisuutta ilmaisevaa to-rakennetta ja venäjän vastaavaa čtoby-infiniittirakennetta. Kiinnostavaa on, että esimerkiksi englannissa tarkoituksen ilmaisemiseen käytetään huomattavasti useammin infiniittistä kuin finiittistä rakennetta. (Ks. tark. Eskola 2002, 157-170; myös Eskola 2005.) Kuten tunnettua, kirjoitettu suomi perustuu pitkälti käännöskieleen, jonka taustalla eli lähtötekstien kielinä ovat nimenomaan edellä mainittujen englannin ja venäjän tavoin indoeurooppalaiset kielet, tärkeimpinä ruotsi ja saksa mutta myös latina ja kreikka.

Leena Nieminen $(1985,27-133,139)$ on pro gradu -tutkielmassaan käsitellyt finaalirakenteen esiintymistä Matteuksen evankeliumin eriaikaisissa suomennoksissa Agricolasta nykykieleen. Nieminen kuvaa finaalirakenteen käyttöä aineistossaan "hajanaiseksi"; eniten esiintymiä on vuoden 1938 Uudessa testamentissa. Myös Pirkko Forsman Svensson (1992, 85-91; ks. myös Vvks, luku 39.4) on tarkastellut finaalirakenteen esiintymistä vanhassa kirjasuomessa, pääasiassa 1600 -luvun saarnakirjallisuudessa. Hänen mukaansa A-infinitiivin translatiivin osuus kaikista infinitiiveistä vastaa 1600 -luvun saarna- ja asetusteksteissä nyky-yleiskieltä, mutta muodon käyttö finaalisessa merkityksessä on vanhassa kirjasuomessa harvinaisempaa kuin nykysuomessa. Nykysuomen tapaan (ks. Ikola 1974, 49-50; Ikola-Palomäki-Koitto 1989, 315-316) 160o-luvun aineiston finaalirakenteet ovat joitakin poikkeuksia lukuun ottamatta lähes yksinomaan hallitsevan lauseen kanssa samasubjektisia (Forsman Svensson 1992, 87).

3 Ikolan, Palomäen ja Koiton (1989) tutkimus perustuu Lauseopin arkiston (Turun yliopisto) aineistoon, joka pohjautuu pääasiassa 190o-luvun puolivälin jälkeisillä vuosikymmenillä tehtyihin murrenauhoituksiin (ks. esim. mt.). 


\section{Neljä osatutkimusta finaalirakenteen käytöstä kirjoitetussa suomen kielessä}

Tässä luvussa analysoidaan finaalirakenteen käyttöä tutkimusaineistoissa. Luvuissa 3.1 ja 3.2 rakennetta tarkastellaan diakronisesta näkökulmasta kautta kirjasuomen historian. Tarkasteltavina ovat kaksi kirjakielen kehityksen kannalta keskeistä lajia, raamatunkieli ja lakikieli. Luvuissa 3.3 ja 3.4 rakennetta analysoidaan puolestaan synkronisesta näkökulmasta. Luvussa 3.3 fokus on yhden kirjoittajan finaalirakenteen käytön tekstilajittaisessa vaihtelussa; luvussa 3.4 näkökulma laajenee kieleltään eritaustaisten kirjoittajien ja tekstien tarkasteluun.

\subsection{Diakroninen näkökulma: tutkimus Uuden testamentin suomennoksista}

\subsubsection{Osatutkimuksen lähtökohdat ja tavoitteet}

Koska suomen kirjakieli kehittyi käytännössä uskonnollisessa kontekstissa ja koska hengellinen kirjallisuus säilyi vuosisatojen ajan kirjallisuuden valtavirtana, kirjakielen ilmiöiden kehityksen tarkastelu on syytä aloittaa raamatunsuomennoksista. Vanhimpia tekstejä tarkastellaan tyypillisesti käännöskielenä: analysoitavana on lopputuloksen lisäksi prosessi, jossa kääntäjät ovat hakeneet puhutusta suomen kielestä riittävän hyviä vastineita lähtökielten konstruktioille. Likimääräinen vastine ilmeisesti ainakin saksan tarkoitusta ilmaiseville $u m . . z u$ ja ruotsin för att -tyyppisille rakenteille on löytynyt murteiden Ainfinitiivin translatiivista, josta sitten vieraiden kielten taustatuella saattoi kehittyä nykyinen finaalirakenteena tunnettu ilmaisutyyppi.

Ensimmäisen osatutkimuksen tavoitteena on selvittää finaalirakenteen esiintymistiheys viidessä eri-ikäisessä Uuden testamentin suomennoskatkelmassa sekä suhteuttaa tulokset toisiinsa. Tarkasteltavina teksteinä ovat Mikael Agricolan Uusi testamentti 1548, vuoden 1642 Biblia, Antti Lizeliuksen ${ }^{4}$ toimittama vuoden 1776 kirkkoraamattu, vuoden 1938 kirkolliskokouksen käyttöön ottama suomennos sekä uusin, vuoden 1992 Raamattu. Puolet kustakin 35000 saneen osa-aineistosta on evankeliumeista ja puolet Paavalin kirjeistä. Agricolan teksteissä, jotka muodostavat aineiston vanhimman osan, evankeliumit ovat saaneet kirjeitä enemmän vaikutteita klassisista kielistä (Itkonen-Kaila 1997, 71-73). Korostetusti tietyltä taholta tulevan käännösvaikutuksen eliminoimiseksi osatutkimuksen aineisto onkin koottu eritaustaisista teksteistä.

\subsubsection{Finaalirakenteen esiintymisfrekvenssit Uuden testamentin käännöksissä}

Uuden testamentin käännöksissä esiintyvien finaalirakenteiden esiintymisfrekvenssejä koskevat laskelmat on koottu taulukkoon 1. Suhteessa muihin osa-aineistoihin Agricolan teksteissä finaalirakenteita on niukasti; myös 1600-1700-luvun käännöksissä5 rakennetta

4 Lizeliuksen kirjallista tuotantoa käsitellään myös luvussa $3 \cdot 3$.

5 Silva Kiurun (1993) mukaan Agricolan kielen lauserakenteita on tiivistetty kauttaaltaan vuoden 1642 Bibliaan muun muassa muuttamalla sivulauseita lauseenvastikkeiksi. Yhtenä tyyppinä Kiuru mainitsee Agricolan että-sivulauseista tiivistetyt finaalirakenteet (mts. 55-56). 
tavataan harvakseltaan verrattuna 1900-luvun käännöksiin. Rakenteen esiintyvyys Uuden testamentin kielessä onkin vuosisatojen kuluessa moninkertaistunut, ja ero vanhimpien ja 1900-luvun suomennosten välillä on merkittävä. Aineisto on ilmaisutyypin kirjakielisen käytön kuvaajana erityisen todistusvoimainen, koska kysymys on valtaosin samasisältöisistä teksteistä.

Taulukko 1. Finaalirakenteen esiintyvyys viidessä eri-ikäisessä Uuden testamentin suomennoksessa.

\begin{tabular}{|c|c|}
\hline Aineisto & Rakennetta / 35 ooo sanetta \\
\hline 1548 & 8 \\
\hline 1642 & 24 \\
\hline 1776 & 19 \\
\hline 1938 & 87 \\
\hline 1992 & 67 \\
\hline
\end{tabular}

Luvussa 2.2 määritellyn kaltainen finaalirakenne on Agricolan teksteissä suhteellisen harvalukuinen. Varhaisimmassa käännöksessä A-infinitiivin translatiivi ei näytä vielä erikoistuneen tarkoituksen ilmaisemiseen. Sillä onkin myöhempään käyttöön verrattuna enemmän esimerkiksi referatiivista käyttöä (HERRA aiatteli haiottaxens Tytteren Zionin mwrit), ja rakenne esiintyy myös asemissa, joissa nykyisin tavattaisiin A-infinitiivin perusmuoto (hen io cauuan halasi hende nädhexens). Finaalirakenne näyttää nousseen kirjakieleen muulta taholta kuin kansanmurteista. Todennäköisin selitys on suomentajien havaitsema riittävä funktionaalinen vastaavuus A-infinitiivin translatiivin ja joidenkin lähtökielten rakenteiden välillä.

Mikäli kirjakielen vakiintumisen katsoisi yksiselitteisesti edistäneen finaalirakenteen käyttöä tarkoituksen ilmaisukeinona, voisi olettaa, että tulos olisi sisällöllisesti kumulatiivinen pienimmästä esiintymämäärästä (1548) suurimpaan (1938) ja että kaikki ne raamatunjakeet, jotka muissa tarkasteltavissa teksteissä on ilmaistu finaalirakennetta käyttäen, sisältäisivät rakenteen myös vuoden 1938 suomennoksessa. Näin ei kuitenkaan ole. Jakeittainen kartoitus (evankeliumien ja kirjeiden alusta kohtiin Luuk. 5:14 ja 2. Kor. 10:2 ${ }^{6}$ ), jossa merkitään finaalirakenteen sisältäviä jakeita x:llä ja rakenteen puuttumista vastaavasta jakeesta o:lla sekä asetetaan havainnot ikäjärjestykseen, tuottaa 13 erilaista rakenteen esiintymän ja rakenteen puuttumisen kombinaatiota. Yhdessä ne edustavat 68:aa raamatunjaetta. Näistä useammin kuin kahdesti esiintyviä ovat yhdistelmät oooxo (22), oooox (14), oooxx (9), oxxxx (5) ja oxooo (4). Odotuksenmukaisesti yleisin on tilanne oooxo (ks. esimerkki 2), jossa rakenne esiintyy vain vuoden 1938 käännöksessä. On myös melko tavallista, että rakenne on ilmaantunut vasta uusimpaan suomennokseen (oooox) tai se esiintyy molemmissa 1900-luvun käännöksissä (oooxx). Finaalirakenteen

6 Koska 35000 sanan otos ulottuu eri käännöksissä hieman eri kohtiin, jakeittainen vertailu on toteutettu vain kaikille yhteisen osuuden osalta. 
esiintyminen kaikissa suomennoksissa Agricolaa lukuun ottamatta (oxxxx) on kokonaisesiintymämäärien valossa ymmärrettävää. Rakenteen käväisy Bibliassa (oxooo) sittemmin käännöksiin uudelleen ilmestymättä kuvastaa rakenteen vakiintumattomuutta kirjakielen ensimmäisinä vuosisatoina.

Aineistossa on vain yksi sellainen Uuden testamentin jae, jossa kaikki suomentajat ovat päätyneet likipitäen samanlaiseen A-infinitiivin translatiivin sisältävään ratkaisuun (ks. esimerkki 1). Tämä jae esiintyy Markuksen evankeliumissa (Mark. 7:4).

1) Ja palio muita ouat quin he otit pitexens quin on Jomaastioiten ia emberiten ia cupariastioiten ia Peutedhen pesemiset. (Agricola)

Ja he otit paljo muutakin pitäxens / cuin on: juomaastiain / kiwiastiain / ja waskiastiain / ja pöytäin pesemiset. (Biblia)

Ja monta muuta on, jotka he ovat ottaneet pitääksensä, jota on: juomaastiain, kivi-astiain, ja vaski-astiain ja pöytäin pesemiset. (1776)

ja paljon muuta on, mitä he ovat ottaneet noudattaakseen, niinkuin maljain ja kiviastiain ja vaskiastiain pesemisiä. (1938)

Monia muitakin tapoja he ovat ottaneet noudattaakseen, kuten juomamaljojen, saviruukkujen ja pronssiastioiden pesuja. (1992)

Nykykielen näkökulmasta esimerkin 1 rakenteita voi vaivoin pitää finaalisina. Missään tapauksessa niitä ei voi pitää Ikolan (1974) tai Wiikin (1981) näkemyksen mukaisina lauseenvastikkeina. Suurin muodollinen este on relatiivipronominin korrelaattina oleva hallitsevan lauseen ja synteettisen rakenteen yhteinen objekti (Agricolan versiossa intransitiivilauseen subjekti) eli vuoden 1938 käännöksen paljon muuta ja sen vastineet muissa käännöksissä (palio muita, paljo muutakin, monta muuta, monia muitakin tapoja), mutta myös tarkoituksen merkitys on väkinäinen. Ottaa, saada ja viedä ovat murreaineistossa yleisiä hallitsevan lauseen verbejä silloin, kun rakenteessa oleva A-infinitiivin translatiivi määrittää päälauseen objektia tai on itse objektin asemassa ${ }^{7}$, esim. Isävaina otti ne [kivet] ajakses (Ikola-Palomäki-Koitto 1989, 321-324). Ottaa/saada/viedä-verbiä määrittävät finaalirakenteet saattavatkin edustaa ilmaisutyypin vanhinta kantaa, joka sittemmin on konstruktionaalistunut omaksi muodon ja merkityksen kombinaatiokseen samalla, kun hallitsevan lauseen verbivalikon laajentuminen on aluksi jossakin rajatussa kontekstissa mahdollistanut rakenteen erillisen objektin ja varsinaisen finaalirakenteen synnyn.

Kun saman jakeen eri-ikäisiä käännöksiä vertaillaan, havaitaan, että useissa tapauksissa kääntäjät ovat tehneet valintansa hallitsevan lauseen adverbiaalin asemassa olevan jotta- tai että-sivulauseen ja finaalirakenteen välillä. Myös luvussa 2.1 mainitut vaihtoehtoiset ilmaisutyypit ovat käytössä varsinkin uusimmissa teksteissä. Vanhimmissa käännöksissä konditionaalimuotoinen pitää-apuverbi MA-infinitiivin instruktiiviin liittyneenä saa usein finaalisen tehtävän. Esimerkki 2 (Luuk. 1:17) ilmentää sitä kirjavuutta, jolla

7 Viimeksi mainitut tapaukset on rajattu tämän tutkimuksen ulkopuolelle (ks. luku 2.1). 
tarkoitusta on ilmaistu (tai jätetty ilmaisematta) viidessä eri-ikäisessä suomennoksessa. Vuoden 1938 käännöksen finaalirakennetta vastaavat Agricolan pitää + MA-infinitiivin instruktiivi sekä Biblian ja vuoden 1776 suomennoksen E-infinitiiviin perustuva, nykykielen modaalirakennetta muistuttava muodoste. Vuoden 1992 käännöksessä on päädytty ratkaisuun, jossa finiittiverbein (kulkee, kääntää) ilmaistut toiminnat ovat samanarvoisia ja jossa mikään aines lauseessa ei ilmaise, että jälkimmäisellä verbillä ilmaistun toiminnan toteutuminen on ensimmäisellä verbillä ilmaistun toiminnan tarkoitus.

2) Ja hen edheskeupi henen edhellens Elian Hengen ia Auwun cansa / ette henen kiendemen pite Iseden sydhemet Lasteins tyge (Agricola)

Ja käy hänen edelläns Elian hengellä ja woimalla / käändäin Isäin sydämet lastens tygö (Biblia)

Ja hän käy edellä hänen edessänsä Eliaan hengellä ja voimalla, kääntäin isäin sydämet lasten tykö (1776)

Ja hän käy hänen edellään Eliaan hengessä ja voimassa, kääntääksensä isien sydämet lasten puoleen (1938)

Hän kulkee Herran edelläkävijänä Elian hengessä ja voimassa, hän kääntää isien sydämet lasten puoleen (1992)

Finaalirakenteen perustehtävä on täydentää hallitsevan lauseen predikaattia suhteuttamalla se kuvattujen tapahtumien syy-seuraussuhteisiin. Se vahvistaa tekstin koheesiota, mutta sen esiintyminen tai puuttuminen ei useinkaan vaikuta kertomuksen etenemiseen. Siksi sen rinnalla esiintyy evankeliumiteksteissä kirjava joukko käännösvastineita.

\subsection{Diakroninen näkökulma: tutkimus lakisuomesta}

\subsubsection{Osatutkimuksen tavoitteet ja lähtökohdat}

Finaalirakennetta käsittelevässä toisessa osatutkimuksessa tarkastellaan rakenteen esiintymistä eri-ikäisissä lakiteksteissä. Tutkimuksen tarkoituksena on selvittää, vaihteleeko finaalirakenteen esiintymisfrekvenssi lakikielessä eri aikoina. Rinnakkaiset diakroniset tutkimukset (luvut 3.1 ja 3.2) tuottavat kiinnostavaa vertailtavaa tietoa, sillä vanhaa uskonnollista kieltä ja vanhaa lakikieltä pidetään yleisesti erilaisina. Varhaisen laki- ja virkakielen on myös sanottu olevan uskonnollista kieltä kehittymättömämpää (esim. Rapola 1935, 353; Kuutti 2010, 127). Aineisto on koostettu neljää eri vuosisataa edustavista ja aihepiiriltään mahdollisimman hyvin toisiaan vastaavista lakiteksteistä. Kukin osa-aineisto sisältää 35000 sanetta, ja sitä pienemmät aineistot on suhteutettu vertailukelpoisuuden saavuttamiseksi yhtä suuriksi. Osa-aineistot esitellään lyhyesti seuraavaksi.

Ensimmäisen suomenkielisen lakikirjan käänsi Tukholman suomalaisessa seurakunnassa työskennellyt pappi Martti (myös Mårten tai Martinus Olai) 1580-luvulla. Koska alkuperäinen käsikirjoitus on kadonnut, aineistona hyödynnetään käännöksen vanhimpana kopiona pidettyä Tukholman koodeksia (Pajula 1955, 58-61; Pihlajamaa 2000, 217-224). Aineistoon sisältyy tekstiä maanlainsuomennoksen kuninkaan kaaresta, 
naimisen kaaresta, perimisen kaaresta, maakaaresta, rakennuskaaresta ja kauppakaaresta $^{8}$. Aiemmat erilliset maan- ja kaupunginlait jäivät käsikirjoituksiksi, ja ne korvasi vuonna 1734 säädetty valtakunnanlaki, jonka suomennos Ruotzin waldacunnan laki painettiin vuonna 1759. Alkuperäisen käännöksen teki Samuel Forseen, ja painoversioon sisältyvät myös Erik Johan Paleenin korjaukset. (Pajula 1960, 90-110.) Ruotzin waldacunnan lain aineisto koostuu maa-, kauppa- ja rakennuskaaresta. Monin tavoin ansioitunut, 1800-luvun kansallisiin merkkihenkilöihin kuuluva Elias Lönnrot ei ollut tyytyväinen käännökseen (Lönnrot 1857, esipuhe) vaan teki sen maakaaresta ja kauppakaaresta uudet suomennokset, jotka julkaistiin vuonna 1857 Suomi-aikakauskirjassa. Teksti kuuluu aineistoon kokonaisuudessaan. Nykykielen aineisto on kerätty oikeusministeriön Finlexverkkopalvelusta. Siihen kuuluu Kauppalaki, Maakaari sekä Maankäyttö- ja rakennuslaki 19. luvun 133. pykälään asti.

\subsubsection{Finaalirakenne lakisuomessa}

Finaalirakennetta esiintyy eniten Lönnrotin (1857) käännöksessä. Muissa teksteissä esiintymiä on selvästi vähemmän, mutta Martin (1580-1.) aineistossa niitä on kuitenkin enemmän kuin Ruotzin waldacunnan lain (1759) aineistossa ja Finlexin (2018) aineistossa. Tarkat esiintymämäärät on esitelty taulukossa 2. Seuraavassa on esimerkkivirkkeet (3-6) jokaisesta osa-aineistosta.

3) Ei mahda yxikän metzä wochta itzellens pytä quin kuningas, cosca hän taruitze nauttiaxens ia ei mutoin. (Martin maanlainsuomennos, Rakennuskaari, 23 §.)

4) Ei mahda myös kengän maalla ylösostaa maan rijstaa, sitä siellä eli cauppacaupungisa myydäxens. (Ruotzin waldacunnan laki, Kauppakaari, 6. luku, $1 \S$.)

5) Täysikäinen, joka vihasta ja vainosta repii, siirtää tahi kääntää rajoja ja pyykkejä, tahi välimerkkejä, taikka panee toisia maahan, sillä hämmentääksensä toisen rajajuoksun, sakotettakoon neljäkymmentä taaleria ja menettäköön kunniansa. (Lönnrot, Maakaari, 13. luku, 3 §.)

6) Jos ostaja haluaa torjua vastaanottamansa tavaran, hänen on myyjän lukuun ryhdyttävä kohtuullisiin toimenpiteisiin huolehtiakseen tavarasta. (Finlex, Kauppalaki, 15. luku, 72 §.)

$8 \quad$ Kaarella viitataan tiettyyn aihepiiriin kuuluvaan lakikokonaisuuteen. 
Taulukko 2. Finaalirakenteen esiintymien määrä lakikielen aineistoissa.

\begin{tabular}{|l|c|}
\hline Aineisto & Rakennetta / 35 00o sanetta \\
\hline Martin maanlainsuomennos (1580-1.) & 12 \\
\hline Ruotzin waldacunnan laki (1759) & 6 \\
\hline Lönnrot (1857) & 31 \\
\hline Finlex (2018) & 4 \\
\hline
\end{tabular}

Martin maanlainsuomennos ja Ruotzin waldacunnan laki edustavat osatutkimuksessa vanhan kirjasuomen aineistoa. Kuten esiintymämäärät osoittavat, varhaiset lakitekstien kääntäjät eivät ole erityisesti suosineet finaalirakennetta. Varhainen lakikieli olikin vielä varsin kankeaa käännöskieltä. Varhaisnykysuomen kautta edustavassa Lönnrotin käännöksessä vanhempien lakitekstien käännösratkaisuja on korvattu finaalirakenteella. Silva Kiuru (1996, 314-315) on kuvaillut Lönnrotin lainsuomennosten lauserakenteita kaikkiaan äärimmäisen synteettisiksi. Lönnrotin lakitekstin finaalirakenteiden esiintymisfrekvenssin voi todeta vastaavan pitkälti rakenteen käyttöä hänen muussa tuotannossaan, erityisesti oppineille henkilöille tarkoitettujen tekstien osalta (ks. luku 3.4.2). Huomionarvoista on, että julkaisunsa esipuheessa Lönnrot arvostelee aiempaa lakikieltä, erityisesti "ruotsalaisen lauseen sana sanalta seuraamista". Finaalirakenne lienee vaikuttanut hänen kielikorvaansa tavoiteltavalta, koska hän on viljellyt sitä useammin kuin aiemmat lainsuomentajat.

Edellä esitetyt esiintymämäärät osoittavat, ettei finaalirakenne ole koskaan ollut erityisen yleinen suomalaisessa lakikielessä, joskin Lönnrotin käännöksessä rakennetta esiintyy huomattavasti muuta aineistoa yleisemmin. Diakroninen tutkimus tuo esiin kielen kehitysvaiheiden keskinäiset erot: eri kausilla lakikieltä on tuotettu eri tavoin. Vanhan kirjasuomen kaudella käännöslakikieli noudatti lähtötekstiä hyvin tarkasti myös rakenteellisesti. Varhaisnykysuomen kaudella lakikieli oli edelleen käännöskieltä mutta tietoinen kielenhuolto vaikutti teksteihin aiempaa enemmän. Nykysuomen kaudella taas lakikieli on supisuomea, jota käännetään tarvittaessa muille kielille.

Kuten edellä taustoittavassa luvussa todettiin, finaalirakenne esiintyy nykysuomen käännöskielessä selvästi useammin kuin alkuperäissuomessa (Eskola 2002, 168-169). Varhaisnyky- ja nykysuomen lakikielestä voidaan tehdä hyvin samansuuntaisia huomioita, sillä vähiten esiintymiä on lähtökohtaisesti suoraan suomeksi kirjoitetussa Finlexaineistossa. Nykylakikielessä on myös tietoisesti pyritty selkeyttämään hankaliksi miellettäviä rakenteita (Piehl-Räsänen-Kankaanpää 2009). Kiinnostava osatutkimuksen tulos on myös se, että tarkasteltavan rakenteen vähäisen esiintymisfrekvenssin osalta nykylakikieli muistuttaa enemmän kirjoitetun lakisuomen varhaisia vaiheita kuin 1800-luvun lakikieltä. Koska lakikieli on 1800-luvulle asti käännöskieltä, avaisi finaalirakenteen vastineiden systemaattinen selvittäminen lähtöteksteistä mahdollisesti rakenteen käytön taustoja. Tämä on yksi monista tutkimuksen esille nostamista jatkotutkimusaiheista. 


\subsection{Tekstilajinäkökulma: finaalirakenne Antti Lizeliuksen teksteissä}

\subsubsection{Osatutkimuksen tavoitteet ja lähtökohdat}

Finaalirakennetta käsittelevässä kolmannessa osatutkimuksessa tarkastellaan rakenteen esiintymistä 1700-luvun teksteissä tekstilajin näkökulmasta. Tekstilajit liittyvät erottamattomasti kieltä käyttävien yhteisöjen elämään ja muuttuvat yhteisön viestinnän tarpeiden mukaan. Ennen 1700-lukua suomenkielinen kirjoitettu kieli käsitti lähinnä uskonnollisia tekstejä ja laki- ja asetustekstejä. Näitä on käsitelty edeltävissä osatutkimuksissa (luvut 3.1 ja 3.2). 1700-luvulla suomenkieliset tekstilajit monipuolistuivat, mikä mahdollistaa sen, että aineistosta voidaan tehdä laaja-alaisempaa tekstien vertailua kuin edeltävien vuosisatojen kirjallisesta tuotannosta. 1700-luku oli valistuksen aikaa, mikä vaikutti erityisesti julkaistun suomenkielisen tietokirjallisuuden määrään; vuosisadan loppupuolella ilmestyivät myös ensimmäiset suomenkieliset sanomalehdet.

Kolmannessa osatutkimuksessa analysoitavaksi on valittu yhden 1700-luvun kirjoittajan, Antti Lizeliuksen, tuotantoa, jotta finaalirakenteen käyttöä on mahdollista tarkastella mahdollisimman puhtaasti tekstilajin kannalta. Lizeliuksen tekstit tarjoavat tekstilajinäkökulmasta vanhan kirjasuomen kontekstissa poikkeuksellisen monipuolisen aineiston. Lizelius (1708-1795) syntyi Tyrväällä, ja hänen kielensä edustaa satakuntalais-hämäläistä murretta. Lizelius oli Turun koulun kollega ja Pöytyän ja Mynämäen kirkkoherra. Häntä voidaan pitää suomenkielisen maallisen kirjallisuuden perustajana ja suomenkielisen kansanvalistustyön aloittajana. (Ikola 1976, 6.) Aineisto koostuu seuraavista teksteistä:

1. Pöytyän ja Mynämäen kirkonkokousten pöytäkirjat ${ }^{9}$ ovat vuosilta 1756-1761 ja 1761-1771. Pöytäkirjat käsittelevät monentyyppisiä asioita, kuten kirkon ja pappilan korjaamista, pitäjän jyväaittaa, köyhäinhoitoa sekä seurakuntalaisten uppiniskaisuutta ja riitoja. (Ks. tark. Ikola 1976, 9.)

2. Suomenkieliset Tieto-Sanomat on ensimmäinen suomenkielinen sanomalehti. Vuosina 1775-1776 ilmestynyt lehti sisältää talonpojille tarkoitettuja kirjoituksia maanviljelystä, karjanhoidosta ja tautien parantamisesta. Lehdessä opetetaan myös maantieteen alkeita ja kerrotaan pieniä ulkomaan uutisia. (Ks. tark. esim. Häkkinen 1994, 151.) Tietosanomien tavoitteena oli ennen kaikkea kansan valistaminen. Tavoitteena voidaan nähdä olleen myös suomen kielen kehittäminen. (Ikola 1976, 7.)

3. Lizelius toimitti Raamatun kahteen kertaan, vuonna 1758 ja vuonna 1776. Näistä jälkimmäinen, vanha kirkkoraamattu, on valittu tutkimusaineistoksi. Aineisto käsittää Matteuksen ja Markuksen evankeliumit sekä osan Luukkaan evankeliumista.

4. ”Tiedotuskirja Tämän Mynämäen Pitäjän, erinomattain Pohjanpuolisen korpikunnan Jumalan palveluxen pitämisen muodosta; mutta kaikkein erinomaisemmasti tämän Bethelin kappelin Wehmalaisten kyläsä alkuperustuksesta, wapaudesta,

9 Pöytyän kirkonkokousten pöytäkirjat käsittävät 5122 ja Mynämäen pöytäkirjat 12364 sanetta, yhteensä 17486 sanetta. Sanomalehtiaineisto käsittää 24 498, Raamatun aineisto 35000 ja Tiedotuskirja 9267 sanetta. 
wihkimisestä ia toimeen saattamisesta" on käsikirjoitukseksi jäänyt kertomus Mynämäen Vehmalaisten kylän vaiheista. Teksti on vuodelta 1780 , ja sitä voidaan pitää ensimmäisenä suomenkielisenä kotiseutututkimuksena. (Häkkinen 1994, 128.) Tiedotuskirja alkaa kaukaa historiasta, suomalaisten pakanallisista palvontamenoista; siinä kuvataan myös kristinuskon tuloa Suomeen ja uskonpuhdistusta. Tämän jälkeen päästään kertomaan Mynämäen kirkoista ja jumalanpalveluksesta. Noin puolet tekstistä käsittelee Vehmalaisten kirkon ja hautausmaan rakentamista ja vihkiäisiä. (Otava 1931, 26; Ikola 1976, 8.)

\subsubsection{Finaalirakenne Antti Lizeliuksen teksteissä}

Finaalirakenteiden määrä vaihtelee Lizeliuksen teksteissä tekstilajeittain. Alla olevat esimerkit 7 ja 8 havainnollistavat Lizeliuksen finaalirakenteen käyttöä.

(7) Englantisa on nykyisin yxi köyhä mies, joka kowasa pakkaisesa puitten puuttesa rupeis rikkomaan wanhaa arkkua, josa hän hawaitzi olewan kahden kertaisen pohjan, löytänyt pohjain wälistä 240. Kulta rahaa, jotka hän waihetti, niillä puita ostaxensa ja holhoaxensa köyhää pesäkuntaansa. (Lizelius 1776, 48.)

(8) Sitte pyysit Seuracunnan vanhimmat vapautta saattaxensa tätä asiata tällä erällä päätöxeen, ettei he tarvitzisi usiammasti tästä vaivaa nähdä, johon suostuttua, kysyttin, mikä sijs heidän ajatuxensa olis? (Lizelius 1765, 65.)

Taulukossa 3 on esitetty, kuinka monta finaalirakennetta kussakin tekstilajissa esiintyy 35000 sanetta kohden. Huomiota kiinnittää ensinnäkin esiintymien vähäinen määrä sanomalehtitekstissä. Sanomalehtiteksti on tavalliselle kansalle suunnattua, ja sen pääasiallinen funktio on kansan valistaminen. Tekstin on oltava helppolukuista ja helposti ymmärrettävää. Ikola $(1976,11)$ kuvaakin Tietosanomien tyyliä yksinkertaiseksi ja nasevaksi. Hän toteaa myös, että Lizeliuksen oli mahdollista kirjoittaa Tietosanomissa parhaana pitämäänsä suomea ja että lehden kieli onkin selvästi Tyrvään murteen värittämää. Ikolan huomiot sopivat hyvin yhteen sen kanssa, että Lizelius on käyttänyt finaalirakenteen kaltaista synteettistä ja kirjakielistä ilmaisukeinoa tekstissään vain vähän ja ilmaissut finaalisuutta mahdollisesti muilla keinoin.

Taulukko 3. Finaalirakenne Antti Lizeliuksen teksteissä tekstilajeittain.

\begin{tabular}{|l|l|}
\hline Tekstilaji & Rakennetta / 35 00o sanetta \\
\hline Tiedotuskirja & 49 \\
\hline Raamattu & 20 \\
\hline pöytäkirjateksti & 18 \\
\hline sanomalehtiteksti & 7 \\
\hline
\end{tabular}


Lizeliuksen raamatunsuomennoksessa on lähes kolminkertainen määrä finaalirakenteita verrattuna hänen sanomalehtitekstiinsä. Siinä missä sanomalehtitekstin kirjoittaminen on ollut vapaata, Raamatun kieleen ovat vaikuttaneet monet kielelliset tekijät, kuten lähtöteksti ja kääntämisen yleiset periaatteet, mutta myös kielenulkoiset tekijät, kuten tuomiokapitulin ohjeet. Raamattua tuli kääntää niin, että sen alkuperäinen sanoma säilyi mahdollisimman tarkkana, mutta toisaalta kielen tuli olla sellaista, että pappien lisäksi tavallinen kansa pystyi sitä lukemaan. Raamatun kielellä on myös pitkät perinteet verrattuna muihin tarkasteltaviin tekstilajeihin. Antero Niemikorven $(1996,50)$ mukaan Lizeliuksen Raamatun tekstin kielellinen perusrakenne onkin pitkälle samanlainen kuin vuoden 1642 Biblian. Vaikka raamatunsuomennokset tukeutuvat aina myös edeltäviin käännöksiin, voitiin edellä ensimmäisen osatutkimuksen yhteydessä todeta, että finaalirakenteiden määrä vaihtelee huomattavasti suomennoksittain. Rakenteen käytön voikin eri käännöksissä katsoa kertovan kääntäjän valinnoista sekä hänen näkemyksestään ideaaleista käännösratkaisuista.

Käännöskielitausta ei luultavasti ole olennaisesti lisännyt finaalirakenteiden määrää Lizeliuksen raamatunsuomennoksessa, sillä suoraan suomeksi kirjoitetuissa teksteissä tapauksia on lähestulkoon yhtä paljon tai enemmän kuin Raamatussa. Lizeliuksen raamatunkäännöksessä ja pöytäkirjoissa rakenteita on suunnilleen yhtä paljon, vaikka ne edustavat hyvin erityyppisiä tekstejä. Lizelius oli ensimmäinen, joka alkoi käyttää suomea pitäjänkokousten pöytäkirjoissa (Otava 1931, 28-29). Vaikka pöytäkirjat eivät ole käännöskieltä, niissä saattaa olla käännöskielelle tyypillisiä piirteitä, koska ruotsinkieliset tekstit toimivat suomenkielisten pöytäkirjatekstien esikuvina. Pöytäkirjojen tarkoitus on kuvata kokouksen kulku tiiviisti ja tarkasti, ja tekstin tyylin voi katsoa olevan jopa lakonista. Finaalirakenteet ovat tiiviitä ja lyhyitä verrattuna niitä vastaaviin jotta-sivulauseisiin. Onkin luontevaa, että rakennetta käytetään tekstilajissa, jolle on ominaista tiivis ilmaisu.

Kotiseutututkimusta edustavassa Tiedotuskirjassa finaalirakenteiden määrä on merkittävästi suurempi kuin muissa tekstilajeissa. Tiedotuskirjan tekstin ei ole ollut tarpeen olla yhtälailla yksinkertaista ja kansankielistä kuin esimerkiksi valistavan sanomalehtitekstin. Tiedotuskirja on myös suunnattu rajatummalle vastaanottajajoukolle, ja sen sisältö on käsitteellisempää, mikä saattaa osaltaan selittää kirjakielisten finaalirakenteiden suurta määrää. Myös aihe voi vaikuttaa rakenteiden esiintymistaajuuteen. Tarkoitusten ja edellytysten ilmaisemista saattaa esiintyä enemmän historiaa ja kirkon ja hautausmaan rakentamista ja vihkiäisiä kuvaavassa kertomuksessa kuin monia muita aihepiirejä käsittelevissä teksteissä. Jotta voitaisiin tietää varmasti, onko tekstin aihe osasyynä tarkoitusta ilmaisevan rakenteen suureen frekvenssiin, tulisi tarkastella myös muita tarkoitusta ilmaisevia rakenteita kussakin tekstilajissa. 


\subsection{Kirjoittajakeskeinen näkökulma: finaalirakenne 180o-luvun asiateksteissä}

\subsubsection{Osatutkimuksen tavoitteet ja lähtökohdat}

Finaalirakenteen esiintymistä käsittelevän neljännen osatutkimuksen aiheena on rakenteen käyttö 1800-luvun asiatyylisissä teksteissä. Rakenteen esiintymistä tarkastellaan sekä kirjoittaja- että tekstilajilähtöisesti. Keskeisinä kiinnostuksen kohteina ovat, kuinka kirjoittajien kielellinen tausta, tarkasteltavien tekstien alkuperä (suoraan suomeksi kirjoitetut ja käännetyt tekstit), tekstilajit ja tekstien kohderyhmä vaikuttavat finaalirakenteen esiintymisfrekvenssiin. Aineisto on koostettu kahdentoista suomeksi 180o-luvun puolivälin molemmin puolin kirjoittaneen ja julkaisseen kirjoittajan teksteistä. Aineisto perustuu pääasiassa Varhaisnykysuomen tekstikorpuksesta (VNSK) poimittuihin 35 ooo saneen otoksiin; aineistoa on lisäksi täydennetty yhdellä teoksella (Keckman, J. H. 1837). Saman kirjoittajan nimissä korpukseen tallennettu data on eritelty tekstilajeittain; lisäksi on erotettu suoraan suomeksi kirjoitetut tekstit ja käännökset. Kaikkiaan finaalirakenne esiintyy 1800-luvun teksteissä varsin samanlaisena kuin nykysuomessa:

(9) Nämät esimerkit olen antanut osoittaakseni, kuinka hankala tämän ruotsinmukaisen konjunktionin käyttäminen on - - (Ahlqvist 1872, 49).

180o-luku oli kirjasuomen kehityksen kannalta merkittävä vuosisata. Yksi aikakauden tärkeistä tehtävistä oli suomenkielisen tietokirjallisuuden kehittäminen. Tässä työssä keskeisessä asemassa oli tieto-, valistus- ja oppikirjallisuuden kääntäminen, mutta käännöskirjallisuuden rinnalla julkaistiin myös suoraan suomeksi kirjoitettua kirjallisuutta (ks. esim. Häkkinen 1994; Paloposki-Riikonen 2013). 1800-luvulla suomeksi kirjoittaneet henkilöt olivat tyypillisesti akateemisen sivistyksen saaneita eri alojen asiantuntijoita, joille suomen kieli, kansan suomenkielinen sivistäminen ja suomalaisuusasian ajaminen olivat keskeisiä tavoitteita ja kiinnostuksen kohteita. He osallistuivat omalla julkaisutyöllään kielen kehittämiseen ja sivistyskieleksi saattamiseen ja olivat tästä tehtävästään myös tietoisia. Kirjoittajissa oli äidinkieleltään niin ruotsin- kuin suomenkielisiä henkilöitä, joita taustasta riippumatta yhdisti usein vasta aikuisiällä opittu suomen kielen kirjallinen taito.

Tutkimusaineisto on koottu seuraavien kirjoittajien teksteistä: August Ahlqvist (18261889), Gustaf Erik Eurén (1818-1872), Jaakko Juteini (1781-1855), Johan Henrik Keckman (1807-1867), Carl Niklas Keckman (1793-1838), Yrjö Koskinen (Yrjö-Sakari YrjöKoskinen, 1830-1903), Elias Lönnrot (1802-1884), Aukusti Juhana Mela (August Johan Malmberg, 1846-1904), Samuel Roos (1792-1878), Karl G. (Samuli) Suomalainen (18501907), Pehr (Pietari) Ticklén (1792-1838) ja Antero Warelius (1821-1904). Heistä äidinkieleltään suomenkielisiä olivat Ahlqvist, Lönnrot, Suomalainen, Tikkanen ja Warelius ja ruotsinkielisiä Eurén, C. N. Keckman, J. H. Keckman, Koskinen, Mela, Roos ja Ticklén. Kirjoittajien väliset erot suomen kielen kirjalliseen käyttöön harjaantuneisuudessa voivat 
olla huomattavia. ${ }^{10}$ Monien kirjoittajien lapsuuden kotiolot olivat lähestulkoon kaksikieliset, he kuulivat ja myös käyttivät suomea aktiivisesti lapsuudesta asti tai olivat työtehtävissään (esim. maalaislääkärin työ) harjaantuneet suomen käyttöön. Kiinnostavan lisän kirjoittajien kielellisten taustojen kartoitukseen tuo se, että äidinkieleltään suomenkieliset olivat tyypillisesti kotoisin Itä-Suomesta, savo-karjalalaiselta alueelta, ja äidinkieleltään ruotsinkieliset puolestaan Länsi-Suomesta, jossa he myös tyypillisesti työskentelivät. ${ }^{11}$

\subsubsection{Finaalirakenne 180o-luvun kirjoittajien teksteissä}

Seuraavassa tarkastellaan finaalirakenteen esiintymistä 1800-luvun asiatyylisissä teksteissä 1) kirjoittajan äidinkielen, 2) kielimuodon (käännössuomi ja supisuomi) ja 3 ) tekstilajin näkökulmista. Aineistosta tehdyt laskelmat on koottu taulukkoon 4. Analyysi osoittaa äidinkielisen kirjoittajan käyttävän tekstissään keskimäärin 26,5 finaalirakennetta 35000 sanetta kohden. Kaksikielisellä tai kaksikielisen tasoisella kirjoittajalla (Eurén, Mela ja Roos) taajuus vastaa lähestulkoon äidinkielisen käyttöä. Ei-äidinkielisellä ja vasta aikuisiällä suomen käyttöön harjaantuneella rakenteita tavataan keskimäärin 65,5. Äidinkieleltään suomenkieliset kirjoittajat käyttävätkin finaalirakennetta selvästi ei-äidinkielisiä vähemmän. Hyvän esimerkin tarjoaa Lönnrotin ja Ticklénin maailman historiaa esittelevän teoksen, Muistelmia ihmisen elosta kaikkina aikoina, käännös $(1836-1837) .{ }^{12}$ Lönnrot ja Ticklén käänsivät tekstin siten, että ensimmäisen osan työstä suomensi Lönnrot (s. 1-195) ja jälkimmäisen Ticklén (s. 196-). Vertailu osoittaa, että rakenteen käyttö eroaa kääntäjillä merkittävästi: Lönnrotilla esiintyy 48 ja Ticklénillä 115 tapausta 35000 sanetta kohden. ${ }^{13}$ Lönnrot edustaa äidinkielistä eteläisestä Suomesta, Uudeltamaalta, kotoisin olevaa ja itämurteita suosivaa kirjoittajaa ja Ticklén puolestaan ei-äidinkielisiä PohjoisPohjanmaalta kotoisin olevaa länsisuomalaisen puhekielen tuntevaa kirjoittajaa.

Vaikka kaikkien kirjoittajien kielitaustasta ei ole käytettävissä yksityiskohtaista tietoja, voi finaalirakenteen esiintymisfrekvensseissä nähdä selviä kielitaustasidonnaisia tendenssejä. Aineiston perusteella on vaikea pitävästi esittää, kumpi vaikuttaa rakenteen esiintymiseen voimakkaammin, kirjoittajan äidinkieli vai tietyn murteen tunteminen ja käyttö. Tämä johtuu siitä, että aineiston äidinkieliset kirjoittajat edustavat pitkälti itäistä kielenkäyttöä ja ei-äidinkieliset läntistä. Kuten edellä on käynyt ilmi, rakenteen esiintyminen

10 Hyvän esimerkin suomen ja ruotsin kirjallisen käytön hallinnassa ilmenevistä eroista molempia kieliä hyvin taitavalla kielenkäyttäjällä tarjoaa Helsingin yliopiston ensimmäinen suomen kielen lehtori, suomen kielen tutkija ja kielenhuoltaja C. N. Keckman. Irmeli Pääkkösen mukaan Keckman taisi oululaisen porvarisperheen poikana puhuttuina molemmat kielet lapsuudesta asti. Sivistyksen kieli ja siten kirjakieli oli hänelle kuitenkin ruotsi, mistä johtuu, että hän varsinkin kiireessä tai taloudellisia asioita käsitellessään vaihtoi kielen ruotsiin. (Päk̈könen 1994, 22-25.) Suomen kielen asiatyylinen käyttö tuotti ongelmia myös äidinkieleltään suomenkieliselle ja suomen kielen asemaa monin tavoin ajaneelle sekä suomen kielen professorina toimineelle Lönnrotille (ks. esim. Krohn 1931, 9-10).

11 Kirjoittajien kielitaustoja ei ole mahdollista esitellä tässä erikseen, mutta ne on huomioitu analyysissa.

12 Suomennoksen pohjana on C. F. Beckerin alun perin saksankielisen teoksen Weltgesichte vuosina 1829-1835 julkaistu ruotsinnos C. F. Beckers Werldshistoria (ks. Mänttäri 2013, 221).

13 Tämä on huomattavasti enemmän kuin muissa osatutkimuksessa tarkasteltavissa Lönnrotin teksteissä. 
murteissa on kuitenkin varsin vähäistä (n. 0,4 tapausta 35000 sanetta kohden; ks. IkolaPalomäki-Koitto 1989). Tämän tiedon valossa kirjoittajan äidinkieli näyttäytyy murretaustaa merkittävämpänä tekijänä.

Kysymys finaalirakenteen esiintymisfrekvenssistä suoraan suomeksi kirjoitetuissa ja käännetyissä teksteissä on mielenkiintoinen. Eskolan (2002) nykysuomea käsittelevän tutkimuksen mukaan rakenne on käännöksissä yli kaksi kertaa yleisempi kuin supisuomalaisissa teksteissä. Vaikka Eskola tarkastelee kaunokirjallisia tekstejä, voi lähtökohtaisesti olettaa, että alkuperä vaikuttaa rakenteen käyttöön myös muissa lajeissa. 180o-luvun asiateksteissä suoraan suomeksi kirjoitetut ja käännetyt tekstit osoittautuvat kuitenkin rakenteen esiintymisen osalta jokseenkin yhteneviksi, tosin niin, että käännöksissä rakennetta esiintyy jonkin verran enemmän (ks. taulukko 4). Esimerkiksi äidinkieleltään suomenkielisen Ahlqvistin supisuomalaisissa teksteissä finaalirakenteita on keskimäärin 27 ja käännöksissä 32 tapausta 35000 sanetta kohden. Aineistossa ei-äidinkielisten suoraan suomeksi kirjoitetun tekstin määrä on varsin rajallinen, mutta esimerkiksi sopii Koskisen väitöskirja Nuija-sota, sen syyt ja tapaukset (1857-1859). Teoksessa rakenteiden määrä on $76 / 35000$ (tekstilajin vaikutusta frekvenssiin tarkastellaan jäljempänä). Keskimäärin äidinkieleltään suomenkielisten suoraan suomeksi kirjoitetussa tekstiaineistossa esiintyy 23 ja ei-äidinkielisten 62 finaalirakennetta (ks. suhteista myös taulukko 4). ${ }^{14}$

Taulukko 4. Finaalirakenne 180o-luvun supisuomalaisissa ja käännetyissä asiateksteissä eritaustaisilla kirjoittajilla.

\begin{tabular}{|l|c|c|c|}
\hline Rakennetta / 35 ooo sanetta & äidinkieli suomi & äidinkieli ruotsi & yhteensä \\
\hline supisuomalainen teksti & 23 & 62 & 42,5 \\
\hline suomennos & 29,5 & 59 & 44 \\
\hline yhteensä & 26,5 & 60,5 & 43 \\
\hline
\end{tabular}

Viimeisenä finaalirakenteen esiintymiseen vaikuttavana tekijänä tarkastellaan tekstilajia ja sitä kautta tekstin vastaanottajaa. Vaikka aineisto koostuu asiateksteistä, se on heterogeeninen, sillä siihen sisältyy muun muassa tekstityypin, käyttötarkoituksen, aiheen ja kohderyhmän osalta erityyppisiä julkaisuja. Koska muuttujia on useita ja aineisto suhteellisesta laajuudestaan huolimatta rajallinen, ovat päätelmät yleisluonteisia. Analyysin tulos on, että finaalirakennetta esiintyy enemmän tietokirjoissa, erikoisalojen teoksissa ja oppikirjoissa kuin tavalliselle kansalle ja erityisesti naisille tai lapsille osoitetuissa

14 Kielimiesten kirjeet muodostavat havaintoja tukevan vertailuaineiston. VNSK:een sisältyy huomattava kirjekokoelma Ahlqvistilta, C. N. Keckmanilta ja Lönnrotilta. Äidinkieleltään suomenkielisten (itämurteista puheenpartta käyttävien ja/tai kannattavien) Lönnrotin ja Ahlqvistin kirjeissä esiintyy 28 finaalirakennetta 35000 sanetta kohden. Äidinkieleltään ruotsinkielisen C. N. Keckmanin finaalirakenteiden määrä on huomattavasti korkeampi, 78 , mikä vastaa käytännössä rakenteen esiintymistä hänen käännetyssä asiaproosatekstissään (73/35 00o). 
valistusteksteissä. Voidaankin olettaa, että yksinkertaista ja helposti ymmärrettävää tekstiä tavoiteltaessa synteettisen rakenteen käyttöä on vältetty. Vastaava huomio tehtiin edellä Lizeliuksen tekstien osalta (luku 3.3). Kuinka tietoisia kielenkäyttäjien valinnat ovat olleet ja kuinka pitkälle ne perustuvat yleiseen mielipiteeseen erityyppisten tekstien ihanteista, on kiinnostava kysymys, jonka selvittäminen jää myöhemmän tutkimuksen tehtäväksi.

Muiden vaikuttimien minimoimiseksi tekstilajikysymystä on syytä tarkastella äidinkieleltään suomenkielisten kirjoittajien teksteistä. Esimerkiksi Suomalaisen (1885-1886) naisille osoitettu kielenkäyttöopas sisältää (suhteutettuna) 10 tapausta ja Lönnrotin talonpojille kirjoitettu lääkärikirja 2 finaalirakennetta 35000 sanetta kohden. Vastaavasti Suomalaisen geometrian oppikirjassa (1876) rakenteita on 28 ja Lönnrotin historiatekstissä 48 tapausta 35000 sanetta kohden (vrt. myös Lönnrotin lakiteksti 31/35 0000). Monet tekijät, kuten aihe ja kohderyhmä, vaikuttavat syntaktisiin valintoihin ja ratkaisuihin. Vaikka tekstien yksityiskohtainen analyysi ei ole tässä mahdollista, voidaan vaihtelun todeta olevan huomattavaa saman kirjoittajan erityyppisissä asiateksteissä.

Neljäs osatutkimus osoittaa, että finaalirakenteen käyttö 1800-luvun asiateksteissä on kirjoittajakohtaista ja erityisesti äidinkielestä riippuvaa. Muita esiintymiseen vaikuttavia tekijöitä ovat tekstin alkuperä, tekstilaji ja kohderyhmä. Rakenteen käyttö yliedustuu ennen kaikkea ei-äidinkielisillä kirjoittajilla, ja oppineelle lukijakunnalle osoitetuissa teksteissä rakennetta tavataan enemmän kuin yleistajuisissa valistus- ja ohjeistusteksteissä. Vaikka tekstilajien suhde ei todennäköisesti ole Ikolan, Palomäen ja Koiton (1989) tutkimuksessa yhteismitallinen tämän tutkimuksen aineiston kanssa, voidaan finaalirakenteen käytön kuitenkin todeta olevan keskimäärin huomattavasti yleisempää 1800-luvun yleiskielisessä kirjallisessa käytössä kuin 1900-luvun yleiskielessä (1800-luvun aineistossa keskimäärin 43 ja 1900-luvun aineistossa n. 14 esiintymää 35000 sanetta kohden). Kaikkiaan tutkimustulosten perusteella voi todeta, että kirjakielisenä piirteenä pidettävä finaalirakenne on saanut $1800-$ luvulla mahdollisesti paljonkin pontta auktoriteettiasemassa toimineille ei-äidinkielisille kirjoittajille ominaisesta kielenkäytöstä.

\section{Kokoavaa tarkastelua}

Finaalirakenne on kirjakielinen ilmaisukeino, jonka käyttöön vaikuttavat monet tekijät. Tässä tutkimuksessa rakennetta on lähestytty tarkastelemalla sen esiintymistä kirjoitetussa suomen kielessä aina kirjakielen alkuajoista nykysuomeen asti. Artikkelissa on selvitetty rakenteen toteutumista eri aikoina, eri tekstilajeissa, eritaustaisissa teksteissä ja eritaustaisilla kirjoittajilla.

Raamatunkäännösten ja lakitekstien analyysi osoittaa, että varhaisimmassa kirjasuomessa eli 1500-luvun teksteissä finaalirakenteen käyttö on suhteellisen vähäistä. 1600- ja 1700-luvuilla rakenteen suosiossa tapahtuu tekstilajien välillä selvä muutos: raamatunkielessä rakennetta esiintyy yli kolminkertainen määrä lakikieleen verrattuna. Määrällisen huipun finaalirakenne saavuttaa lakikielen aineistossa 1800-luvun puolivälissä ja Uuden 
testamentin aineistossa vuoden 1938 käännöksessä. 1900-luvun loppuun ja 2000-luvulle tultaessa rakenteen käyttö vähenee molemmissa aineistoissa. Lakikielen osalta muutos on kuitenkin merkittävästi suurempi kuin raamatunkielessä. Voidaankin todeta, että finaalirakenteen käyttö nykylakisuomessa on hyvin vähäistä. On kuitenkin hyvä huomata aineiston laatuun liittyvä muutos: 2000-luvun lakiteksti ei ole enää käännöskieltä vaan suoraan suomeksi kirjoitettua. Raamatunkielen osalta käyttöfrekvenssi on hyvin toisenlainen. Rakennetta voikin pitää jopa tyypillisenä piirteenä 1900-luvun Uuden testamentin kielelle (vrt. 1900-luvun UT:n käännösten keskimäärin 77 ja yleiskielen n. 14 esiintymää 135000 sanetta).

Analyysin laajentaminen edellistä monipuolisempaan tekstiaineistoon vahvistaa tekstilajin olevan merkittävä finaalirakenteen frekvenssiin vaikuttava tekijä. Mikäli kirjoittaja pyrkii tuottamaan korostetun selkeää, yksinkertaista ja helppolukuista kieltä, rakennetta käytetään suhteessa vähemmän kuin silloin, kun tällaista tarvetta ei ole. Rakenne onkin harvinainen tavalliselle kansalle suunnatuissa valistus- ja ohjeistusteksteissä, kun taas oppineelle lukijakunnalle osoitetussa kirjallisuudessa sitä esiintyy enemmän.

Nykysuomea koskeva aiempi tutkimus (Eskola 2002) osoittaa finaalirakenteen yliedustuvan käännösteksteissä supisuomalaisiin teksteihin verrattuna. Viitteitä vastaavanlaisesta erosta on nähtävissä lakikielen diakronisessa tutkimuksessa. Diakroninen vertailu ei kuitenkaan ole yhtä yksiselitteistä kuin synkroninen vertailu, sillä tekstin koostamisen ja kääntämisen ideaalit poikkeavat toisistaan eri aikoina. 1700- ja 1800-lukujen aineistojen valossa käännöstekstien ja supisuomalaisten tekstien välillä ei kuitenkaan vaikuta olevan erityisiä eroja. Muut taustatekijät tuntuvatkin vaikuttavan rakenteen käyttöön huomattavasti tekstin tuottamistapaa enemmän. Tekstilajin ja vastaanottajan lisäksi merkittäväksi tekijäksi osoittautuu kirjoittajan tausta. Yleistäen voi todeta, että äidinkieleltään suomenkieliset (käytännössä pääosin itämurteiden alueelta kotoisin olevat) kirjoittajat viljelevät finaalirakennetta sekä suoraan suomeksi kirjoittamissaan että kääntämissään teksteissä selvästi vähemmän kuin äidinkieleltään ruotsinkieliset (käytännössä pääosin länsimurteiden alueelta kotoisin olevat) suomeksi kirjoittavat henkilöt.

A-infinitiivin translatiiviin perustuvat konstruktiot ovat vielä vanhimmassa kirjasuomessa hakeneet muotoaan. Finaalirakenne näyttää tutkimusten valossa kirjakieliseltä rakenteelta, mutta sen alkuperä voi silti olla murteellinen, ja sen kehitys nykyiseen muotoonsa saattaa olla yhteydessä esimerkiksi hallitsevan lauseen laajentuneeseen verbivalikkoon. Sysäys muutokseen on voinut tulla käännösten lähtökielistä, joiden systemaattinen tarkastelu on oman tutkimuksensa aihe. Käsillä oleva tutkimus nostaa esille myös monia muita kysymyksiä ja jatkotutkimuksen aiheita. Näitä ovat finaalirakenteen käyttöfunktiot ja niiden kehittymisen tarkastelu, samoin finaalirakenteen käyttö suhteessa muihin tarkoitusta ilmaiseviin rakenteisiin, kuten että- ja jotta-sivulauseisiin ja verbikantaiseen -minen-substantiivin translatiiviin. Näitä tutkimalla voitaisiin hahmottaa tarkoitusta ilmaisevien rakenteiden verkosto ja analysoida ilmaisutyyppien keskinäisiä suhteita. Käsillä olevan artikkelin keskeisenä tarkoituksena on toimia avauksena aiempaa kokonaisvaltaisempaan synteettisiä nominaalirakenteita käsittelevään tutkimukseen. Se 
osoittaa, että finaalirakenteen kehitystä on mahdollista seurata kirjakielisistä lähteistä ja vielä useista eri näkökulmista. Vastaavalla tavalla voidaan historiallisessa syntaksin tutkimuksessa valaista myös monien muiden rakenteiden käyttöä.

\section{Lähteet}

\section{Aineslähteet}

Agricola, Michael Olai 1548: Se Wsi Testamenti. Stockholm. VKS.

AHLQvist, August 1872: Arveluja alkusoinnun altaisesta alkuperäisyydestä. Kieletär. 4. vihko, 33-46. Frenckell, Helsinki.

Biblia 1776. Saatavilla: www.finbible.fi.

Finlex-säädöstietopankki. Saatavilla: www.finlex.fi.

Keckman, Johan HenriK 1837: Terveyden Opetus-Kirja yhteiselle kansalle. Frenckell, Turku.

Koskinen, YrJö 1857-1859: Nuija-sota, Sen syyt ja tapaukset. VNSK.

Lizelius, ANTTi 1756-1761: Pöytyän kirkonkokousten pöytäkirjoja. VKS.

— 1761-1771: Mynämäen kirkonkokousten pöytäkirjoja. VKS.

1775-1776: Suomalaiset Tieto-Sanomat. VKS.

1780: Tiedotuskirja. VKS.

LÖNNROT, ELIAS 1836: Muistelmia ihmisen elosta kaikkina aikoina. VNSK.

1838: Suomalaisen Talonpojan Koti-Lääkäri. VNSK.

1857: Kauppakaari ja Maakaari uudesti suomennetut. VNSK.

Martin maanlaki = Kristoffer kuninkaan maanlaki. VKS.

Muistelmia ihmisen elosta kaikkina aikoina. Mehiläinen. Liite. Suomentaen mukaillut Elias Lönnrot (s. 1-195) ja Pehr Ticklén (s. 196-). 1836-1837.

Raamattu 1938. Saatavilla: www.finbible.fi.

Ruotzin Waldacunnan Laki 1734. VKS.

SuOMalainen, Karl Gustaf [SAmuli] 1885-1886: Suomalaisia Keskusteluja Ajan ratoksi suomenkieltä suosiville Suomen naisille I-II. VNSK.

TickLÉn, PeHr 1837: Muistelmia Ihmisen Elosta Kaikkina Aikoina. VNSK.

VKS = Vanhan kirjasuomen korpus. Kotimaisten kielten keskus, Helsinki. [Viitattu 16.2.2018.] Saatavilla: http://kaino.kotus.fi/korpus/vks/meta/vks_coll_rdf.xml.

VNSK = Varhaisnykysuomen korpus. Kotimaisten kielten keskus, Helsinki. [Viitattu 16.2.2018.] Saatavilla: www.kaino.kotus.fi/korpus/180o/meta/180o_coll_rdf.xml.

\section{Muut lähteet}

BeCKer, Carl Friedrich 1829-1835: C. F. Beckers Werldshistoria. Niteet 1-12. N. M. Lindh, Örebro.

EsKola, SARI 2002: Syntetisoivat rakenteet käännössuomessa. Suomennetun kaunokirjallisuuden erityispiirteiden tarkastelua korpusmenetelmällä. Joensuun yliopiston humanistisia julkaisuja 30. Joensuun yliopisto, Joensuu.

— 2005: Lauserakenteiden käytön piirteitä suomennetussa kaunokirjallisuudessa. ANNA MAURANEN ja JARMo H. JANTUNEN (toim.): Käännössuomeksi. Tutkimuksia suomennosten kielestä, 225-243. Tampere Studies in Language, Translation and Culture A1, Tampere.

Forsman Svensson, Pirkкo 1992: Vanhan kirjasuomen nominaalirakenteista. Stockholm Studies in Finnish Language and Literature. Department of Finnish. Stockholm University, Stockholm.

HakAnen, Aimo 1986: Satakuntalaismurteiden lauseenvastikkeista. Sananjalka 28, 17-30. Suomen Kielen Seura, Turku.

HäKKInen, KaISA 1994: Agricolasta nykykieleen. Suomen kirjakielen historia. WSOY, Helsinki. 
IкоLA, Osmo 1974: Lauseenvastikeoppia. Nykysuomen lauseenvastikkeiden ja niihin verrattavien rakenteiden selvittelyä. Tietolipas 76. SKS, Helsinki.

__ 1976: Antti Lizelius suomen kielen viljelijänä. Sananjalka 18, 5-14. Suomen Kielen Seura, Turku.

Ikola, Osmo - PalomäKi, Ulla - Koitto, Anna-Kaisa 1989: Suomen murteiden lauseoppia ja tekstikielioppia. SKST 511. SKS, Helsinki.

ISK = Hakulinen, Auli - Vilkuna, Maria - Korhonen, Rittta - Koivisto, Vesa - Heinonen, TARJA RiItTA - AlHo, IrJa 2004: Iso suomen kielioppi. SKS, Helsinki.

ItKonen-Kaila, Marja 1997: Mikael Agricolan Uusi testamentti ja sen erikieliset lähtötekstit. Suomi 184. SKS, Helsinki.

KiURU, Silva 1993: Agricolan Uusi testamentti ja ensimmäiset Raamattumme. Virittäjä 97 (1), 51-68. Kotikielen Seura, Helsinki.

— 1996: 1800-luvun lainsuomennoskieli. Raimo LAHTI (toim.): Kohti rationaalista ja humaania kriminaalipolitiikkaa, 307-316. Helsingin yliopiston rikos- ja prosessioikeuden sekä oikeuden yleistieteiden laitos, Helsinki.

Krohn, KaARLE 1931: Toimihenkilöt ja toiminnan puitteet. Suomalaisen Kirjallisuuden Seura 18311931. Suomi. 5. jakso, 12. osa, 3-74. SKS, Helsinki.

KuUtti, Pirkko 2010: Varhaiset lainsuomennokset. Heikki E. S. Mattila, Sari Pajula ja Aino Piehl (toim.): Oikeuskieli ja säädöstieto, 107-129. Suomalainen Lakimiesyhdistys, Helsinki.

Mänttäri, Pia 2013: Historiantutkimus. Outi Paloposki ja H. K. Riıkonen (toim.): Suomennetun tietokirjallisuuden historia 180o-luvulta 200o-luvulle, 221-241. SKST 1289. SKS, Helsinki.

Niemikorpi, ANTero 1996: Florinuksen Nomenclatura ja Lizeliuksen vanha kirkkoraamattu. Kaksi vanhan kirjasuomen merkkiteosta nykykielen peilissä. Vaasan yliopiston julkaisuja. Selvityksiä ja raportteja 8. Vaasan yliopisto, Vaasa.

Nieminen, Leena 1985: Lauseenvastikkeiden käyttö Matteuksen evankeliumin eriaikaisissa suomennoksissa. Pro gradu -tutkielma. Suomen kieli. Turun yliopisto, Turku.

Otava, T. K. 1931: Antti Lizelius ja hänen "Suomenkieliset tietosanomansa". SKS, Helsinki.

Pajula, PAAvo 1955: Ensimmäinen lainsuomennos. Lisiä suomalaisen lakikielen varhaishistoriaan. SKS, Helsinki. 1960. Suomalaisen lakikielen historia pääpiirteittäin. WSOY, Helsinki.

Paloposki, Outi - Rironen, H. K. 2013 (toim.): Suomennetun tietokirjallisuuden historia 18oo-luvulta 200o-luvulle. SKST 1289. SKS, Helsinki.

Piehl, Aino - RÄSÄNen, Matti - KankaAnpä̈̈, SAlli 2009: Kohti parempaa säädöskieltä. Kielikello 2/2009, 19-22. Kotimaisten kielten keskus, Helsinki. Saatavilla https://www.kielikello.fi/-/kohtiparempaa-saadoskielta. Luettu 10.10.2018.

PinlajamaA, LaUri 2000: Tukholman suomalaisen seurakunnan papisto 1533-1999. Terttu Pihlajamaa Förlag, Tukholma.

PäÄKKÖNen, IRMELI 1994: Suomalainen sydämestä - Carl Niclas Keckmanin toiminta suomen kielen kehittäjänä. SKS, Helsinki.

Rapola, MartTi 1935: Hartikka Speitzin vuorityö-asetusten suomennos. Virittäjä 39, 344-353. Kotikielen Seura, Helsinki.

SKS = Suomalaisen Kirjallisuuden Seura.

SKST = Suomalaisen Kirjallisuuden Seuran Toimituksia.

Vvks = Virtuaalinen vanha kirjasuomi. Saatavilla http://www.helsinki.fi/vvks/index.html. Luettu 4.5.2018. WiIK, KALEVI 1981: Mikä lauseenvastike on? Virittäjä 85 (1), 21-39. Kotikielen Seura, Helsinki. 


\title{
Duha Elsayed, Kirsi-Maria Nummila, Heidi Salmi and Harri Uusitalo: The final clause in Finnish texts from the $16^{\text {th }}$ century to the present
}

Contemporary Finnish has a compact means of expressing that the action described in an embedded clause expresses the purpose of the action found in the main clause (Hän on ponnistellut lujasti estä|ä|kse|en [prevent+INF+TRANSL+POSS.3SG] neuvottelujen kariutumisen 'He has made a considerable effort to prevent the negotiations from falling through') or that the main clause action is a prerequisite of the action expressed in the subclause (Hän ei ole elänyt tarpeeksi kauan kerto|a|kse|en [tell+INF+TRANSL+POSS.3SG] löydöstään 'He hasn't lived long enough to talk about his discovery'). This non-finite construction, named the final clause (finaalirakenne) at its most scaled-down meaning can even convey simple posteriority (Edmonton meni jatkoon pudot $|a| k s e \mid e n$ [fail+INF+TRANSL+POSS.3SG] seuraavalla kierroksella Minnesotalle 'Edmonton made the playoffs and/but lost against Minnesota in the next round'). The construction consists of the translative form of the A-marked infinitive. A possessive suffix is affixed to the infinite verb form. It usually refers to the subject referent of the main clause.

The final clause appears to be a formation typical to literary Finnish, even though the translative of the A-marked infinitive has some lexicalised uses in local dialects. This paper was written by a group of researchers of Old Finnish who decided to follow the factors behind its frequency in various old texts. As a result, a pilot study on the final clause was conducted.

The construction was investigated from three different perspectives: 1) diachronic changes in religious and legal texts, 2) the effect of genre, and 3) the author's language background. Corpora samples representing Old Finnish, Early Modern and Modern Finnish, each containing 35,000 words, were determined, and the occurrences of final clauses (or constructions close enough to it) were calculated.

The results show that the final clause, like non-finite clauses in general, was still seeking its shape in the earliest biblical and legal texts. Few occurrences of the final clause could be defined in the 16th century texts. However, the translative of the A-marked infinitive had other uses. The final clause spread rapidly in the 19th century, peaking in legal texts by Elias Lönnrot, and then in the Finnish translation of the Bible in the 1930 .

From the beginning, the final clause had a literal tone to it. Antti Lizelius (1708-1795), parson of the counties of Pöytyä and Mynämäki and founder of the first Finnish newspaper, made frequent use of the final clause in his book Tiedotuskirja, a study on local history, while underused it in the newspaper Suomenkieliset Tieto-Sanomat, whose main goal was public enlightenment. Texts of several 19th century authors were investigated in the same manner in order to ascertain the effect their language background had on the use of the final clause. The writers' mother tongue appeared to be a greater factor for this than the status of the text in its original form or translated. Non-native Finnish speakers were three times as likely to use the construction than native speakers.

Many other questions arise from the findings of this paper, which is a preliminary introduction to the so far little researched non-finite construction. Nevertheless, it proved possible to follow the genesis and development of the final clause found in available literary sources.

\author{
Duha Elsayed \\ Kirsi-Maria Nummila \\ Heidi Salmi \\ kirnum@utu.fi \\ hemame@utu.fi \\ Harri Uusitalo \\ htuusi@utu.fi

$\begin{array}{rr}\text { duha.elsayed@utu.fi } & \begin{array}{r}\text { hemame@utu.fi } \\ \text { hirnum@utu.fi kieli ja suomalais-ugrilainen kielentutkimus }\end{array} \\ 20014 \text { Turun yliopisto }\end{array}$

